\title{
Mixofibrossarcoma - Case report
}

\author{
Mixofibrossarcoma - Relato de caso
}

\author{
Walquíria Lima Tupinambá ${ }^{1}$ \\ Januário de Souza Júnior ${ }^{1}$ \\ Carlos Alberto Chirano Rodrigues ${ }^{3}$
}

\author{
Renata Almeida Schettini ${ }^{1}$ \\ Antonio Pedro Mendes Schettini ${ }^{2}$ \\ Flaviano da Silva Oliveira ${ }^{3}$
}

\begin{abstract}
Myxofibrosarcoma, previously known as malignant fibrous bistiocytoma, myxoid variant, is a rare tumor of mesenchymal origin, composed of spindle cells and myxoid stroma. It mainly affects elderly people, involving the lower extremities and frequently extending to the dermis and subcutaneous tissue. The tumor presents high rates of recurrence, and a deep biopsy is required to obtain the correct diagnosis. We report a case of high-grade mixofibrossarcoma characterized by a rapidly growing tumor and the presence of marked cellular pleomorphism and an abundant myxoid matrix.

Keywords: Fibrosarcoma; Histiocytoma, malignant fibrous; Neoplasms; Skin neoplasms

Resumo: O mixofibrossarcoma, previamente conhecido como histiocitoma fibroso maligno, variante mixoide, é um tumor raro, de origem mesenquimal, composto por células fusiformes e estroma mixoide. Acomete mais idosos, envolvendo extremidades inferiores e estendendo-se, em sua maior parte, até a derme e o subcutâneo. Apresenta altas taxas de recorrência e para seu diagnóstico é fundamental a realização de uma biópsia profunda. Relataremos o caso de um mixofibrossarcoma de alto grau, caracterizado por lesão tumoral de crescimento rápido e pela presença de marcado pleomorfismo celular e componente mixoide em abundância.

Palavras-chave: Fibrossarcoma; Histiocitoma fibroso maligno; Neoplasias; Neoplasias cutâneas
\end{abstract}

\section{INTRODUCTION}

${ }^{4}$ Mixofibrossarcoma, previously known as the mixoid variant of malignant fibrous histiocytoma $(\mathrm{MFH})$, is a fibrous soft tissue sarcoma of mesenchymal origin, characterized by myxoid stroma and spindle cell proliferation. ${ }^{1,2,3}$ Since 2002 the WHO has preferred the term Mixofibrosarcoma ${ }^{4}$.

It is a rare tumor, mainly affecting elderly patients, with the majority of cases occurring in the extremities. ${ }^{3,2,4}$ The lesion normally appears as painful and slow-growing dermal or subcutaneous masses, with ill-defined infiltrated borders making it difficult to achieve complete tumor resection. ${ }^{2,4}$

The tumor is classified histologically into three types, according to its cellularity and atypia: low (I), intermediate (II) and high-grade (III). ${ }^{2,3,5,6}$ The tumors are generally characterized by the proliferation of delicate slender or stellar fibroblasts and curved blood vessels suspended in a hyaluronic acid-rich myxoid matrix. ${ }^{4}$ The superficial parts of the tumor appear benign while its deeper parts have the histomorphological features of malignancy. ${ }^{4,6}$ The present report refers to a young male adult patient, with high- grade mixofibrossarcoma.

\section{CASE REPORT}

30-year-old male patient, born in São Paulo and resident in Manaus, developed around three months ago a hard, mobile erythematous lump on the left knee (Figure 1). Before seeking specialized care, 3 surgical drainages of the lesion had been done in one

Received on 09.12.2010.

Approved by the Advisory Board and accepted for publication on 15.01.2011.

* Study undertaken at Alfredo da Matta Foundation (FUAM), Manaus, Brazil.

Conflict of interest: None / Conflito de interesse: Nenbum

Financial funding: None / Suporte financeiro: Nenbum

MD Resident in Dermatology at the Alfredo da Matta Foundation (FUAM), Manaus, Brazil.

MA in Tropical Pathology awarded by the Federal University of Amazonas (UFAM), Dermatologist and Medicine Residency Preceptor at the Alfredo da Matta Foundation (FUAM), Manaus, Brazil.

Dermatologist and Medicine Residency Preceptor at Alfredo da Matta Foundation (FUAM), Manaus, Brazil

(C)2011 by Anais Brasileiros de Dermatologia 
of the Manaus emergency departments, but the lump continued to return. A clinical evaluation was done when the patient first presented at the Dermatology Department, followed by a biopsy. The result was inconclusive.

When the patient returned after one month, we observed a significant growth of the lesion which by then consisted of a scaly, painful tumor measuring approximately $3 \mathrm{~cm} \times 5 \mathrm{~cm}$ (Figure 2). We decided to remove the aggressive and recurrent tumor and send the specimen for histopathological analysis. The excision was performed with a $2 \mathrm{~cm}$ safety margin up to the muscular fascia plane where the tumor was attached. We brought the edges of the wound together to allow healing by secondary intention.

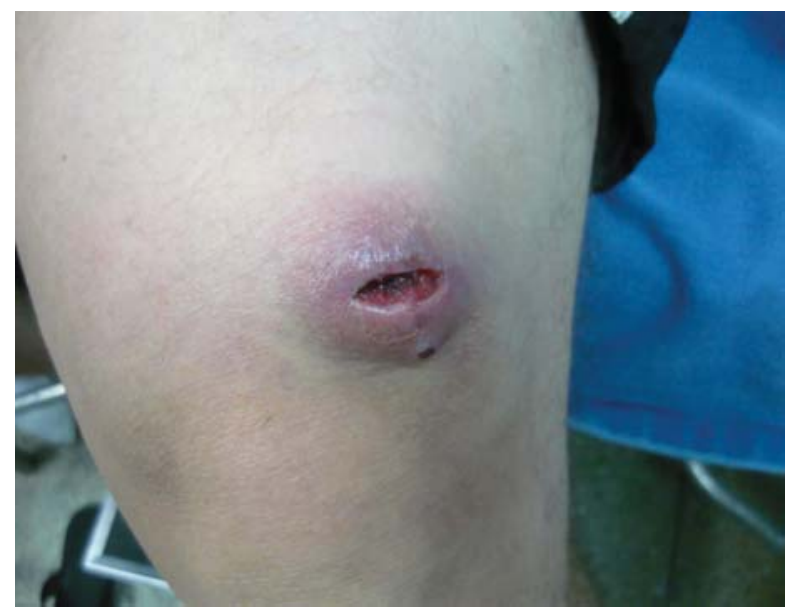

FIgURE 1: Hardened erythematous nodule after surgical drainage

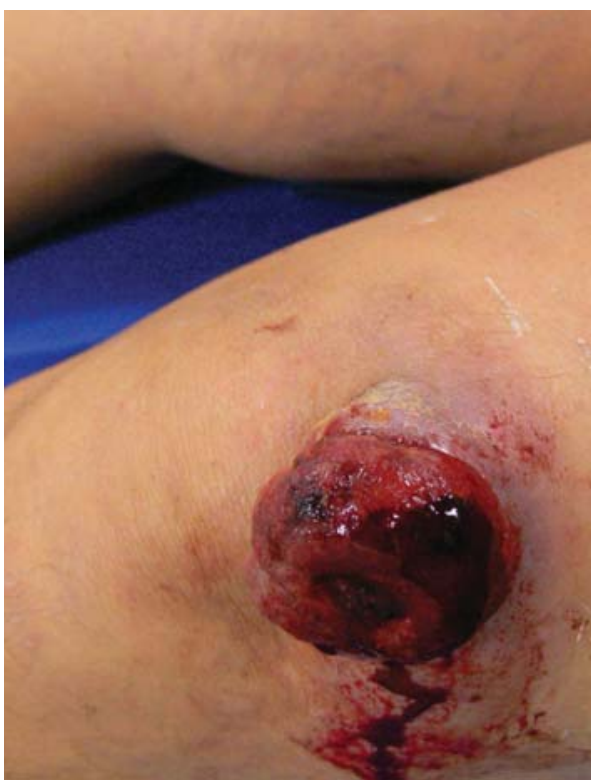

FIGURE 2:

After one

month: scaly

$3 \times 5 \mathrm{~cm}$ tumor on left knee
Histopathology showed an acanthoti epidermis, but most of the changes were located in the deep dermis, where we observed the presence of a proliferation of spindle cells lying in a myxoid stroma, the largest component of the tumor (Figures 3 and 4). We also observed the presence of a large number of atypical bizarre cells and mitotic figures which imparted a high level of indifferentiation to the lesion. We also noted the presence of atypical giant star-shaped cells and curved blood vessels. (Figures 5 and 6).

The material was sent for immunohistochemistry. All the markers tested proved negative - smooth muscle actin, CD34, cytokeratin, desmin and S-100 protein. This result suggested to the team that the lesion was a highly undifferentiated pleomorphic sarcoma. More specifically, the histopathologic characteristics pointed to a mixofibrossarcoma. We then requested a vimentin immunohistochemical assay,

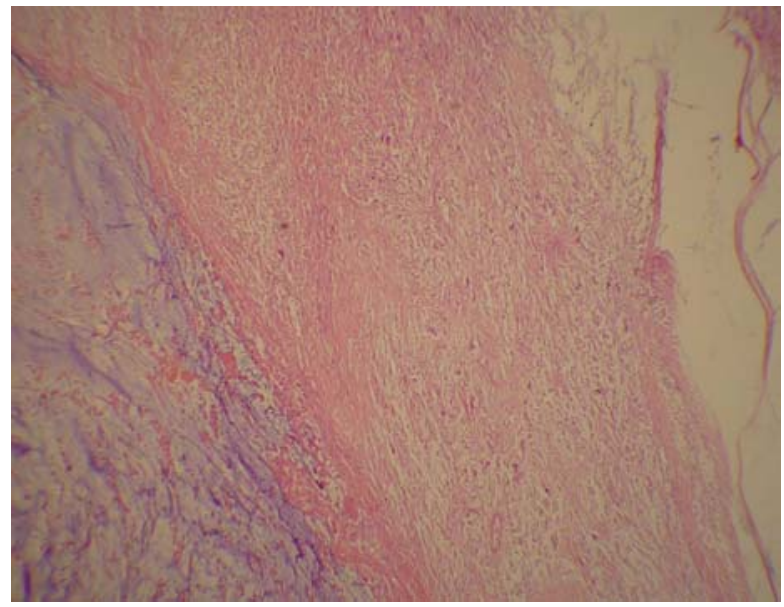

Figure 3: Proliferation of spindle cells associated with myxoid stroma

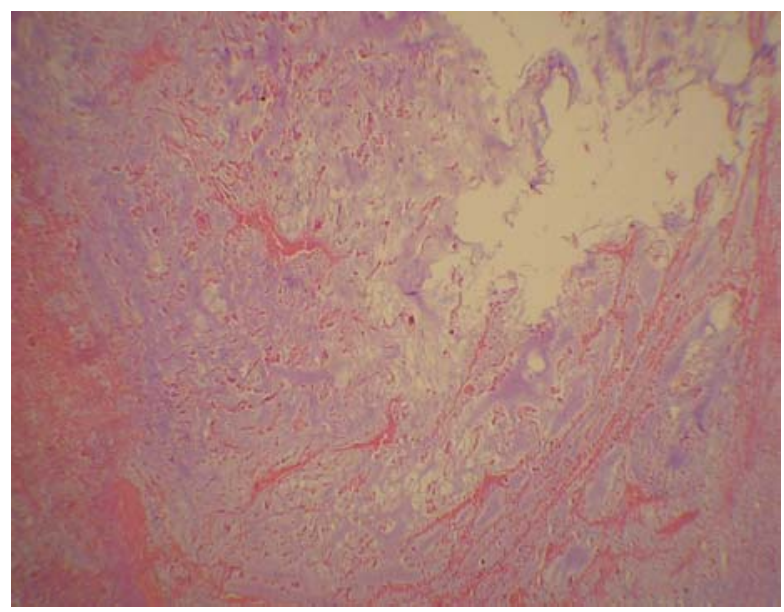

FIGURE 4: Myxoid stroma in more detail 


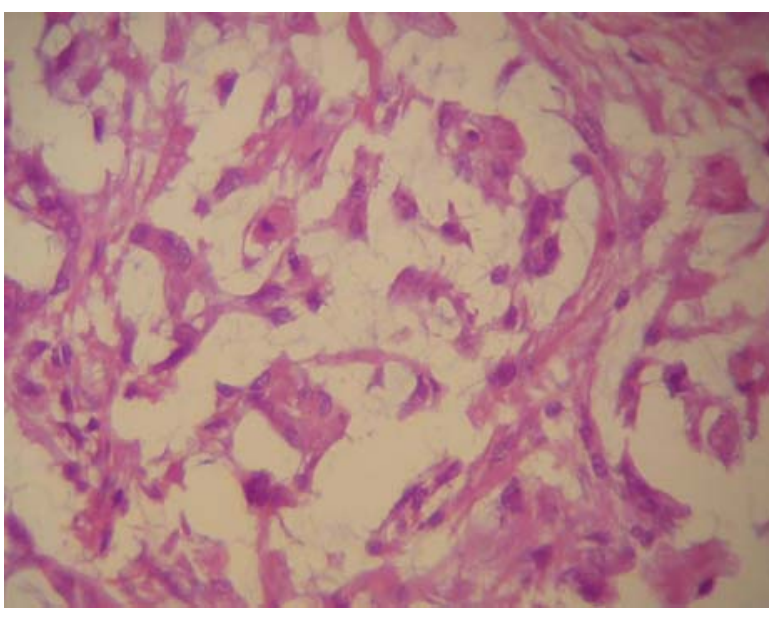

FIGURE 5: Atypical bizarre cells and mitotic figures

which returned a positive result.

Imaging studies did not indicate any invasion of deeper structures and no distant metastasis. The patient was referred to an oncology reference centre for therapeutic assessment and development of a treatment regime.

Large amount of bizarre cells, and atypical mitotic figures gave a high degree of differentiation to injury and called attention to the presence of atypical cells form giant stars and curvilinear vessels (Figures 5 and 6).

\section{DISCUSSION}

Sarcomas, consisting of a heterogeneous group of neoplasms, histologically classified according to the mature tissue they resemble, ${ }^{7}$ are among the neoplasms that dermatologists do not generally encounter on a daily basis.

The case described above concerns a rapidly growing high-grade mixofibrossarcoma in a young adult. This is normally a slow-growing tumor affecting people in their sixties, seventies and to eighties and represents the majority of malignant mesenchymal neoplasms among the elderly. ${ }^{4}$

Skin mixofibrossarcoma may look misleadingly trivial, particularly in superficial skin biopsies. Such tests can easily underestimate the presence of highgrade tumor or even misjudge it as benign. This adds to the difficulties of diagnosing a mixofibrossarcoma. ${ }^{4}$

The histopathology test is the gold standard for establishing a definitive diagnosis of mixofibrossarcoma. ${ }^{5}$ Immunohistochemistry is positive in most cases for vimentin, and in some cases for smooth muscle actin and desmin. ${ }^{6}$

The tumors are divided into low, intermediate and high grade. The main findings in all the tumors,

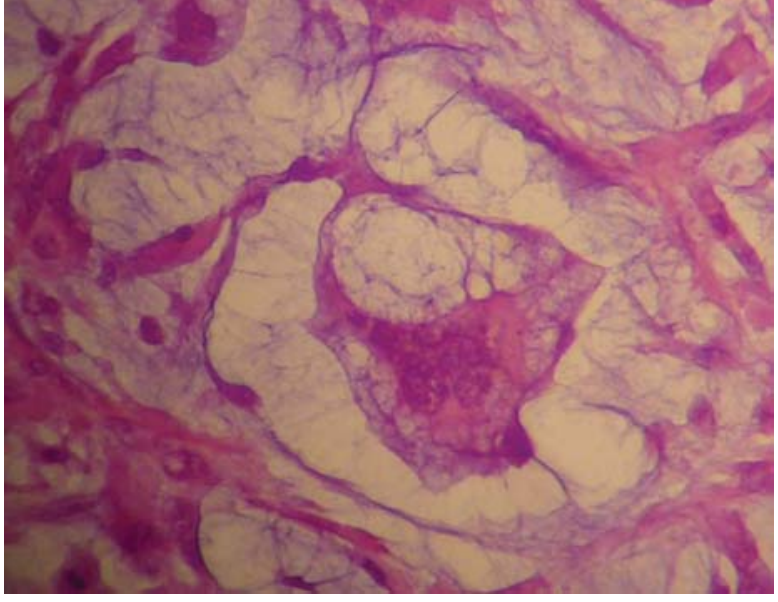

Figure 6: Atypical star-shaped giant cells

regardless of grade, are multinodular growth with incomplete fibrous septa and myxoid stroma. ${ }^{6}$ Low level tumors (I) are characterized by hypocellularity, especially by the most prominent myxoid areas with little atypia and rarely invading fascia and muscle. They may also include pseudolipoblastos, a subtype of tumor cells filled with foamy cytoplasmic vacuoles compressing the core, giving the appearance of a lipoblast as can be seen in liposarcomas. These cells are fibroblasts with vacuoles containing glycosaminoglycans. Although a useful diagnostic finding, this subtype is not always present and other tumors can produce cells with similar morphology. ${ }^{4}$ Intermediate grade (II) tumors are more cellular and pleomorphic, with necrosis but with no extensive solid areas. ${ }^{6}$ Finally, high-grade tumors (III) are densely cellular and with a large amount of cellular pleomorphism, bizarre nuclei, hemorrhage and necrosis areas and usually with few myxoid stroma associated with large solid areas. Many cases, such as what is reported herein, show bizarre multinucleate giant cells with abundant eosinophilic cytoplasm. ${ }^{4,6}$

According to previous studies, grade II and III tumors are genuinely malign on account of their metastatic potential. Meanwhile, grade I lesions are only locally aggressive. ${ }^{3,4}$ We know of no reports of grade I mixofibrossarcoma linked to distant metastesis. ${ }^{5}$ The likelihood of recurrence appears to be regardless of the depth and histological grade of the tumor and may occur in as many of $50-60 \%$ of cases. The risk of metastasis is higher in patients with deep high-grade lesions, whereas $20 \%$ to $35 \%$ of cases of grade II and III may develop metastases. The lungs and bones are the most common sites for these tumors. The five-year survival rate is $60-70 \%^{4,6}$. Since local recurrences however accompany the increasing 
histological grade, grade I mixofibrossarcoma can in due course become metastatic, requiring close monitoring. ${ }^{3}$

Differential diagnosis of mixofibrossarcoma includes other myxoid tumors. The differences are subtle, and it is often hard to distinguish the tumors from one another. Nevertheless, it is vitally important from a clinical point of view to pinpoint the differences between all these myxoid subtypes in order to determine specific therapy regimes and correct monitoring.

Differential diagnosis of high grade mixofibrossarcoma covers other high-grade malignancies such as spindle cell melanoma, myxoid leiomyosarcoma, myxoid liposarcoma and myxoid fibrous histiocytoma. Some of these could be excluded by careful examination and the use of good immunohistochemical data. ${ }^{4}$

\section{REFERENCES}

1. Dore A, Robertson I, Williamson R, Weedon D. Progression of a mixoyd pleomorphic fibroma to myxofibrosarcoma. Australas J Dermatol. 2005:44:287-90.

2. Motoda N, Akiyama M, Aoyagi S, Sawamura D, Shimizu H. Low-grade myxofibrosar coma invaded into the underlying skeletal muscle. J Dermatol. 2007;34:561-4.

3. Willems SM, Debiec-Rychter M, Szuhai K, Hogendioorn P CW, Sciot R. Local recurrence of myxofibrosarcoma is associated with increase in tumour grade and cytogenetic aberrations, suggesting a multistep tumour progression model. Mod Pathol. 2006;19:407-16.

4. Clarke LE, Zhang PJ, Crawford GH, Elenitsas R. Myxofibrosarcoma in the skin. J Cutan Pathol. 2008;35:935-40.

5. Denschalag D, Kontny U, Tempfer C. Orlowska-Volk M. Niemeyer C. Gitsch G. Low-grade myxofibrosarcoma of the vulva in a 15 -year-old Adolescent. Int J Surg Pathol. 2005;13:117-9

6. Fletcher CDM, Unni KK, Mertens F. Myxofibrosarcoma. In: Fletcher CDM, Unni KK, Mertens F, editors. World Health Organization Classification Tumours of soft tissue and bone. Lyon France: IARC; 2002. p. 102-103

7. Fleury Jr LFF, Sanches Jr, JA. Sarcomas Cutâneos. An Bras Dermatol. 2006:81:207-21.
Therapy consists of surgical resection with a safety margin of at least $2 \mathrm{~cm}$ - a recommendation based on the study of 110 patients with mixofibrossarcoma by Merck and collaborators. After an average follow-up of two years, Merk's team found a recurrence rate of $17 \%$ (radical resection) and $79 \%$ (non-radical resection). ${ }^{5}$ Wide excision of the initial injury is recommended, given the possibility of histological and biological progression in local recurrences which can increase metastasic risk. ${ }^{4}$

\author{
MAILING ADDRESS / ENDEREÇO PARA CORRESPONDÊNCIA: \\ Renata Almeida Schettini \\ Avenida Codajás, 25 - Cachoeirinha \\ 69065130 Manaus AM Brazil \\ E-mail: renata_schettini@yaboo.com.br
}

How to cite this article/Como citar este artigo: Tupinambá WL, Schettini RA, Souza Júnior J, Schettini APM, Rodrigues CAC, Oliveira FS. Mixofibrossarcoma - Case Report. An Bras Dermatol. 2011;86(4 Supl 1):S110-3. 